\title{
Formation and early development of the corpus luteum in pigs
}

\author{
B. D. Murphy' ${ }^{1}$ N. Gévry' ${ }^{1}$ T. Ruiz-Cortés ${ }^{1}$, F. Coté2, B. R. Downey² \\ and J. Sirois ${ }^{1}$
}

'Centre de Recherche en Reproduction Animale, Faculté de Médecine Vétérinaire, Université de Montréal, 3200 Rue Sicotte, St-Hyacinthe, Québec J2S 7C6, Canada; and

${ }^{2}$ Department of Animal Science, McGill University, Ste-Anne de Bellevue Québec, Canada

Numerous corpora lutea form from the multiple follicles that ovulate during the oestrous cycle of pigs. Vascular elements invade the follicle from the theca compartment, first centripetally, and subsequently by lateral branching of centripetal veins and arteries. The vessels are the vehicle for dispersion of steroidogenic theca cells throughout the corpus luteum. Mitosis occurs in both the theca and granulosa layers before ovulation, and in luteal cells well into the luteal phase. Luteal cell proliferation undergoes gradual restriction as the corpus luteum matures, but the mechanisms of exit from the cell cycle are unknown. The extracellular ligands that direct luteinization and maintain the corpus luteum include $\mathrm{LH}$, prolactin, insulin and insulin-like growth factors (IGFs). These ligands induce qualitative and quantitative changes in steroid output, with progesterone as the principal product. These changes upregulate the cholesterol synthetic pathways to increase substrate availability. The intracellular regulation of luteinization is complex. A model is presented in which $\mathrm{LH}$ stimulates arachidonic and lineoleic acid metabolism to produce ligands for the nuclear proteins of the peripheral peroxisome activator receptor family. These ligands have downstream effects on cell differentiation and exit from the cell cycle. Luteal function is maintained by interactions among ligands, cholesterol regulatory proteins and constitutively expressed and regulated transcription factors.

\section{Introduction}

The success of gestation in the pig is entwined inextricably with the establishment and maintenance of the corpus luteum. This complex transitory organ develops from follicles as a consequence of ovulation and secretes the progesterone necessary for creating a uterine environment hospitable for survival of embryos and fetuses. Pigs differ from ruminants because the corpus luteum is required for the entire 16 weeks of gestation. Its importance is underlined by the fact that its principal synthetic product, progesterone, can, by itself, maintain gestation in ovariectomized gilts. The focus of this review is the process of luteinization and its aim is to identify the principal unanswered questions about luteal differentiation in pigs. Where possible, answers to these questions are proposed.

Corner (1919) described both the theca and granulosa precursors of luteal cells and the 
histomorphological changes that follow ovulation and result in redistribution of theca cells within the corpus luteum. Both the final destinations of theca cells and the process of luteal angiogenesis, their proposed vehicle of dispersion, are not understood completely. Luteinization is believed to represent terminal differentiation of the granulosa component of the follicle, but little is known about the mechanisms for exit of luteal cells from the cell cycle in any species, and its timing in pigs has not been addressed. Furthermore, the mechanisms effecting the logarithmic increase in steroid output that occurs within a few days after the commencement of luteinization are only beginning to be recognized.

\section{Formation of the pig corpus luteum}

Preovulatory follicle development in the pig has been investigated extensively (for review see Cox, 1997). A well-documented finding is heterogeneity of the developmental process (Grant et al., 1989), resulting in asynchrony in ovulation and consequent corpus luteum formation (Pope et al., 1990). Ovulation and luteinization have been studied less. The evolution of a pig follicle to a young corpus luteum is shown (Fig. 1). The period from the onset of the LH surge to first ovulation was estimated as a mean of $44 \mathrm{~h}$ (Soede et al., 1994) and in equine chorionic gonadotrophin (eCG)-hCG-treated gilts, the mean interval ranges from 34 to $48 \mathrm{~h}$ (Hunter, 1972). During the period between the ovulatory stimulus and expulsion of the ovum, the follicle undergoes changes, including hyperaemia and theca cell hypertrophy. There is rearrangement of the compact layers of granulosa cells to looser associations, characterized by reduced intercellular contact ( $F$ ig. $2 a, b$ ). Vascular remodelling begins before ovulation and incipient invagination occurs at the sites of major vein and artery complexes (Fig. 1). In samples taken approximately $24 \mathrm{~h}$ after ovulation, vascular and associated thecal tissues have not yet breached the follicle wall, but the regions of invagination are still substantially deeper and wider than in preovulatory follicles (Corner, 1919). Soon thereafter, there is evidence of focal decomposition of the follicle wall (Corner, 1919) and invasion of vascular elements into the granulosa compartment. The vascular components spearhead the invasion at the apices of the invaginations and bear theca cells to the lumen of the follicle (Fig. 1). Lateral vascularization throughout the former granulosa compartment occurs, apparently concomitant with the centripetal growth of the arteries and veins.

Corner (1919) described the invasion of the follicle compartment by the vascular elements and theca. He reported the dispersion of thecal cells throughout the luteal parenchyma, where they become disseminated singly or in groups of two or three among the granulosa descendants. Furthermore, Corner (1919) noted that many thecal cells remain near the periphery of the follicle or associate with the vessels that have invaded. His identification was based on the morphological characteristics of these cells and their responses to fixatives. Although the contribution of theca cells to the corpus luteum is not disputed, their ultimate fate and distribution have not been confirmed. It is assumed, but has not been shown conclusively, that theca cells become the small luteal celis that can be separated from their larger counterparts, presumably granulosa cell descendants, on density gradients (Pitzel et al., 1990). There are no definitive markers that can be recognized after the differentiation of the theca precursors into theca-luteal cells. Understanding the fate of theca-luteal cells will allow better understanding of the important processes in luteal formation, the persistence of cell division, angiogenesis and migration of theca cells.

\section{Ligand induction and maintenance of luteinization}

In pigs, luteinization and maintenance of the corpus luteum depends on members of at least three protein families: the gonadotrophins, the cytokine-prolactin family and the family of 

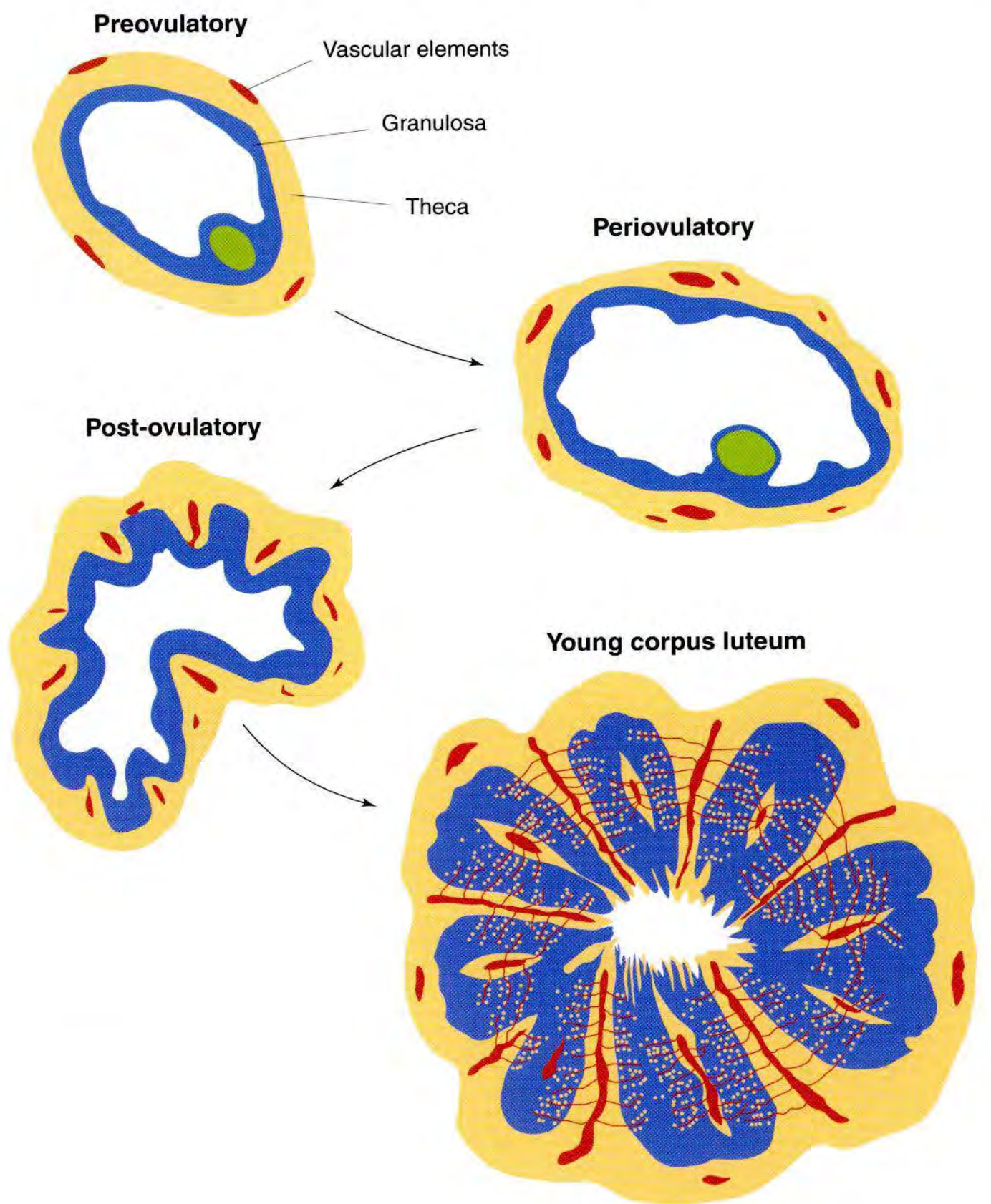

Fig. 1. Development of a pig corpus luteum from a preovulatory follicle. The preovulatory follicle undergoes hyperaemia and enlargement (periovulatory stage) before expulsion of the ovum (post-ovulatory stage) and formation of the young corpus luteum. The granulosa compartment is depicted in blue, the theca and its descendants in yellow, and the vascular elements in red. Incipient intrusion of the vascular elements occurs during the periovulatory period, but the theca-granulosa barrier is not breached until after ovulation. The vascular elements invade the corpus luteum in a centripetal direction, as well as laterally into the luteal parenchyma. Blood vessels are believed to carry theca cells into the luteal parenchyma and to disperse them throughout the corpus luteum. 

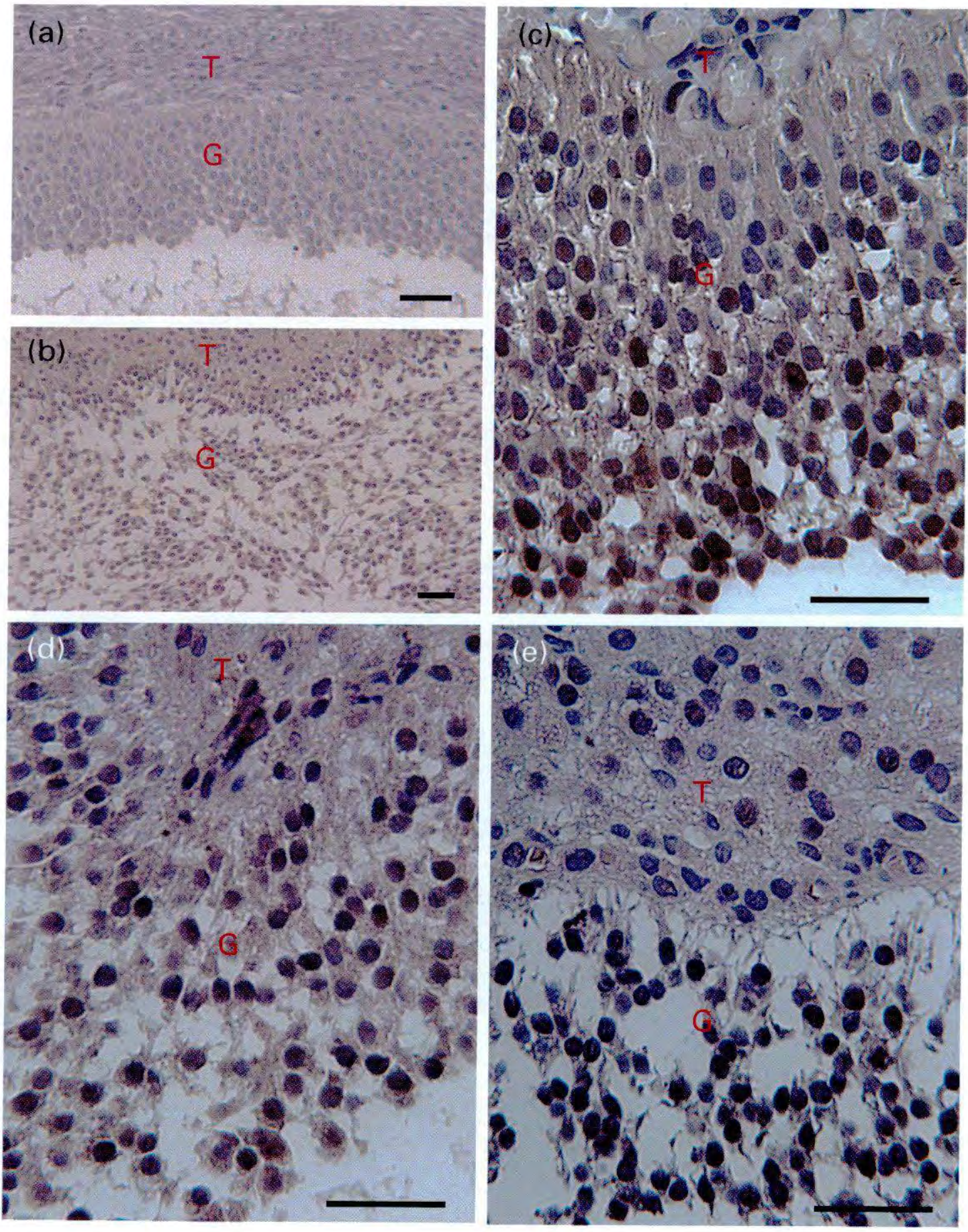

Fig. 2. Photomicrographs of the periovulatory period in follicles from gilts treated with hCG to induce ovulation. Expression of proliferating cell nuclear antigen (PCNA), a marker for cell division, was identified by immunohistochemistry. In all panels cell nuclei with the characteristic brown diaminobenzidine stain are positive for PCNA. (a) Cross-section through a large antral $(7 \mathrm{~mm}$ in diameter) pig follicle subjected to immunolocalization procedures but not exposed to the anti-PCNA antibody. (b) Theca-granulosa interface at 
insulin and insulin-like growth factors (IGFs). The proximal stimulus for ovulation is the preovulatory release of $\mathrm{LH}$ from the pituitary, as in other mammals. In most of the species studied, including pigs (Coté et al., 2001), gonadotrophins provoke expression of an inducible form of the cyclo-oxygenase enzyme (COX-2) by the granulosa cells that catalyses the first rate-limiting step in conversion of arachidonic acid to prostaglandins (Sirois and Richards, 1992). The sequence of COX-2 expression after ovulation has not been investigated in pigs, but it is clearly present and inducible in the corpus luteum at days 9 and 17 of the oestrous cycle (Diaz et al., 2000). A second catalytic route for arachidonic acid is via the lipoxygenase enzymes, resulting in hydroxyeicosatetranoic acids (HETEs). Pharmacological interruption of this pathway reduces the rate of ovulation in pigs (Downey et al., 1998).

The $\mathrm{LH}$ surge is the stimulus for initiation of other events in luteinization, particularly the qualitative and quantitative changes in steroidogenesis. Studies of hypophysectomy in pigs have shown that the pituitary is necessary for luteal support throughout gestation, that $\mathrm{LH}$ is essential in the early corpus luteum and that prolactin plays an important role later in pregnancy (Li et al., 1989). Both $\mathrm{LH}$ and prolactin have luteotrophic effects on pig granulosa cells in vitro (Chedrese et al., 1988).

Luteinization of pig granulosa cells in vitro occurs only when serum is present in the medium (Picton et al., 1999). Serum-borne elements, particularly insulin and IGFs, contribute to luteinization and support of the corpus luteum during the luteal phase. Plasma membranes of pig luteal cells have receptors for IGF-I, and IGF-I binding proteins are expressed differentially in the pig corpus luteum throughout the luteal phase (Wandji et al., 2000a). Insulin and IGFs are essential for the steroidogenic changes that characterize luteal formation in vitro (Pescador et al., 1999; Sekar et al., 2000). Most of the downstream genes that are modulated by these ligands in the corpus luteum have not yet been identified.

\section{Angiogenesis in the pig corpus luteum}

The source of the vasculature that perfuses and maintains the pig corpus luteum is the veins and arteries that invade after ovulation. Histological evidence indicates that the major vessels grow rapidly in a centripetal direction, arriving at the antrum of the former follicle (Fig. 1). Lateral development from the invading vascular components also occurs rapidly (Corner, 1919). The morphology and regulation of angiogenesis in the corpus luteum are the subject of at least five recent reviews (for example see Fraser and Lunn, 2001). Although none of these reviews considers pigs, the principles are expected to apply to this species. The rate of neovascularization in the corpus luteum appears to be higher than for any known tissue, including human tumours. A current view of regulation suggests that $\mathrm{LH}$ precipitates the angiogenic cascade (Fraser and Lunn, 2001). However, the principal stimulus inducing neovascularization is hypoxia, and a case has been made for hypoxia as an angiogenic stimulus in corpora lutea (Reynolds et al., 2000). Results in other species implicate acidic and basic fibroblast growth factors ( $a$ and bFGFs), particularly bFGFs, and vascular endothelial growth factor (VEGF) as the key mediators of luteal angiogenesis (Reynolds et al., 2000). The source of the FGFs is presumed to be the luteinized granulosa cells (Reynolds et al., 2000) and this is consistent with the pattern of occurrence of FGF mRNA in pig follicles and corpora lutea (Guthridge et al., 1992). VEGF is thought to stimulate proliferation of endothelial cells

Fig. 2. continued

$38 \mathrm{~h}$ after hCG treatment, showing the dispersion of the granulosa layers at approximately $3 \mathrm{~h}$ before expected ovulation. (c) Cross-section of an $8 \mathrm{~mm}$ follicle taken from an untreated gilt and (d) $24 \mathrm{~h}$ after hCG and (e) $38 \mathrm{~h}$ after hCG administration. T: theca compartment. G: granulosa compartment. Scale bars represent $25 \mu \mathrm{m}$. 
(Fraser and Lunn, 2001) and migration of endothelial cells into the granulosa parenchyma (Reynolds et al., 2000). Its source may be theca-derived pericytes (Reynolds et al., 2000) or granulosa-luteal cells (Fraser and Lunn, 2001). VEGF is found in pig follicular fluid and is produced by pig follicles during gonadotrophin-stimulated development (Barboni et al., 2000). Both the theca and granulosa compartments contribute, but the latter predominates in overall VEGF synthesis (Barboni et al., 2000). LH greatly reduces expression of VEGF by pig granulosa cells, both in vivo and in vitro (Barboni et al., 2000). These findings contrast with the current view that LH drives angiogenesis via induction of VEGF and its downstream targets in granulosa cells (Fraser and Lunn, 2001). Whether this anomaly reflects differences in experimental design or fundamental differences among pig, ruminant and primate angiogenesis deserves further investigation. Connective tissue growth factor (CTGF) and a tumour inhibitor, MAC-25, have recently emerged as potential modulators of angiogenesis in pig corpora lutea (Wandji et al., 2000b). Although there are some intriguing new findings, the nature of angiogenic stimuli and processes in formation of pig corpora lutea remain unknown.

\section{Luteinization and exit from the cell cycle}

Luteinization is the final phase in differentiation of theca and granulosa cells, a process that begins with formation of the primordial follicle before birth. There is much evidence that pig follicular growth results from hyperplasia of granulosa cells (Morbeck et al., 1992). After ovulation, the prevailing view, derived from other species, is that luteinization results in exit of granulosa cells from the cell cycle. Reprogramming from the proliferative to the differentiated state in rat granulosa cells is complete within 5-7 h after the LH surge (Richards, 2001a). Although functional changes in mammalian theca cells have been described, little is known about their proliferation during luteinization in vivo. In pigs, both theca (Englehardt et al., 1991) and granulosa cells (Pescador et al., 1999; Picton et al., 1999) proliferate and undergo luteinization when cultured with serum. This luteinization, defined as the loss of cytochrome P450aromatase expression and synthesis of large amounts of progesterone as the principal steroid product, can be avoided by culture in serum-free, insulin-supplemented medium (Picton et al., 1999). Granulosa cells incubated under the latter conditions continue to proliferate, albeit somewhat less robustly than in the presence of serum.

Much of the growth of the pig corpus luteum is the result of cellular hypertrophy (Corner, 1919; Ricke et al., 1999) and little information is available on the contribution of cell proliferation. Corner (1919) confirmed that cell division was occurring by observation of the mitotic spindle in theca cells of the periovulatory follicle and in follicles undergoing luteinization. We recently examined cell proliferation by immunohistochemistry using a mitotic marker, proliferating cell nuclear antigen (PCNA), in gilts treated with hCG to induce ovulation (B. D. Murphy, F. Coté, J. Sirois and B. R. Downey, unpublished). Late preovulatory follicles $(6-8 \mathrm{~mm}$ in diameter) displayed the mitotic signal in many cells of the theca. The granulosa cell compartment consists of compact layers of cells, all of which express PCNA strongly (Fig. 2c). At $24 \mathrm{~h}$ after hCG administration, the theca cells are hypertrophied and display numerous PCNA positive cells (Fig. 2d). The granulosa layer is expanded; there is loss of the compactness of the cell layers and evidence of mitosis throughout (Fig. 2d). Ovaries removed at 30 and $34 \mathrm{~h}$ after hCG administration display greater dissociation of the granulosa cell layers, while retaining the same pattern of mitosis in the theca and the granulosa compartments (data not shown). At $38 \mathrm{~h}$ after hCG administration, a few hours before expected ovulation, the rate of mitosis has increased in the theca layers (Fig. 2e). The granulosa cells are nearly dissociated (Fig. 2b); however, the PCNA signal is present, particularly in the most interior layers of cells (Fig. 2e). 
Ricke et al. (1999) demonstrated extensive mitosis in the corpus luteum during the first 4 days after ovulation. About $25-40 \%$ of the mitotic cells are derived from the theca or granulosa, whereas the other mitotic cells represent proliferation of vascular elements (Ricke et al., 1999). Co-localization of mitotic and steroidogenic enzyme signals indicates that luteal steroidogenesis and cell division occur in proliferating cells, particularly early in luteal development. Over the lifespan of the corpus luteum, the labelling index decreases (Ricke et al., 1999) and the mitotic signal is observed rarely in large luteal cells. Thus, it appears that terminal differentiation occurs in the pig corpus luteum. Nonetheless, it is equally apparent that the rat model of rapid and irreversible exit from the cell cycle soon after the ovulatory stimulus (Richards et al., 1998) does not apply to pigs. A more appropriate model includes continued mitosis of the steroidogenic cells well into the luteal phase, with increasing restriction in the capacity to proliferate.

The mechanisms of terminal differentiation in the corpus luteum have begun to be studied, mostly in rodents (Richards et al., 1998; Richards, 2001a,b). The initiation of mitotic division is under the control of members of the retinoblastoma protein family, retinoblastoma protein (pRb), p107 and p130 (Classen and Dyson, 2001). In the hyperphosphorylated state, these proteins permit cell division by liberating the transcription factors of the E2F family, which then upregulate the genes responsible for progression of the cell cycle. Hypophosphorylation of these proteins results in mitotic quiescence by the opposite mechanism, the sequestering of E2Fs (Morgan, 1995). In luteinization, a general pattern emerges in which pRb and p130 are dephosphorylated, thereby impairing the expression and activity of positive regulators of the cell cycle, cyclins D1, D2 and E (Green et al., 2000; Hampl et al., 2000). A second level of regulation is recognized, on the basis of a phenotype of luteal disruption in mice bearing the null mutation for p27Kip1 (Kikokawa et al., 1996), a member of one of the two families of inhibitors of the cyclin-dependent kinases (Zhu and Skoultchi, 2001). In these mice, differentiation of luteal cells appears to occur, as indicated by cytochrome P450side chain cleavage (P450scc) expression, and cyclin D2 activity is repressed; however, active DNA synthesis persists (Tong et al., 1998). Further evidence for a role for these repressors of cyclindependent kinases (CDKs) comes from a study which showed that expression of $\mathrm{p} 27^{\mathrm{Kip} 1}$ and $\mathrm{p} 2{ }^{\mathrm{Cip} 1}$ is increased in granulosa cells of hypophysectomized rats treated with ovulatory doses of hCG (Robker and Richards, 1998). The expression of p27 proteins remains high throughout the lifespan of the corpus luteum in pregnant mice (Hampl et al., 2000). CDK4, expressed in mouse granulosa cells and in the mouse corpus luteum of gestation, complexes with p27 and cyclin D3 (Hampl et al., 2000). A different disruption in the luteal phenotype emerged after null mutation of CDK4, which enhanced expression of $\mathrm{p} 27^{\mathrm{Kip} 1}$ (Tsutsui et al., 1999). It took the form of entrapment of oocytes and aberrant luteal organisation. Cell cycle regulators can participate in both cell proliferation and differentiation, and CDKs regulate transcription of genes that result in differentiation in some tissues (Zhu and Skoultchi, 2001), which could explain the phenotype of the CDK4 knockout mice.

Although progress has been made, our knowledge remains rudimentary. There is no specific information on exit from the cell cycle for pigs, and there is no information on the cell cycle dynamics of theca cells in development of the corpus luteum.

\section{Differentiation of theca and granulosa cells into their luteal counterparts}

Granulosa and theca cells undergo functional differentiation during luteinization. In most of the species studied, the theca of the follicle responds to LH stimulation by synthesis of androgens. These diffuse across the basement membrane to the granulosa compartment where they are aromatized to oestrogens, under the influence of $\mathrm{FSH}$. The latter portion of the 
scheme occurs in pigs, as $3 \beta$-hydroxysteroid dehydrogenase ( $3 \beta-H S D)$, which converts pregnenolone to progesterone, is found in the theca of the growing follicle only (Driancourt et al., 1998). However, pig follicles deviate from the general pattern because the theca cells express aromatase and produce oestrogens that complement the production of granulosa cells (Tsang et al., 1985). In many species, oestrogen concentrations are low or absent in the corpus luteum. In contrast, P450aromatase expression persists in pig corpora lutea (Meduri et al., 1996) and large and small cells of pig corpora lutea maintain the capability to secrete oestrogen (Lemon and Loir, 1977). However, luteinization in pigs engenders alteration of the pattern of steroid synthesis in favour of progesterone, particularly the granulosa cells (Lavoie et al., 1997), as indicated by the early acquisition of the expression of P450scc, which converts cholesterol to pregnenolone, and of 3B-HSD (Meduri et al., 1996). This change is accompanied by a large increase in total steroid output, which requires an extensive increase in the supply of cholesterol, the substrate for steroid synthesis. In pigs, luteinization is characterized by coordinated upregulation of cholesterol synthesis, importation and intracellular trafficking genes, including the low density lipoprotein receptor and sterol carrier protein 2 (Lavoie et al., 1997), steroidogenic acute regulatory protein (StAR), P450scc (Lavoie et al., 1997; Pescador et al., 1997, 1999) and Niemann-Pick C1 protein (Song et al., 1998). Expression of StAR is a key event in granulosa cell remodelling (Pescador et al., 1997, 1999); thus, factors that control this transition are believed to be essential regulators of luteinization.

The pattern of expression of gonadotrophin receptors changes as a pig follicle becomes a corpus luteum. The FSH receptors present on granulosa cells of the follicle are lost during luteinization (Liu et al., 1998). Binding analysis of $\mathrm{LH}$ receptors indicated an initial downregulation, relative to granulosa cells from periovulatory follicles, followed by recovery in the number of receptors as the luteal phase progresses (Gebarowska et al., 1997). Autoradiographic studies indicate that hCC binding in newly formed corpora lutea is mainly peripheral and is more widespread in mid-cycle corpora lutea (Gebarowska et al., 1997). Immunohistochemical localization of the LH receptor supports this interpretation of the early stage: downregulation after ovulation and restriction of the signal to the periphery and to the presumed theca-derived component of the corpus luteum (Meduri et al., 1996). However, the analyses diverge at this point, as immunolocalization using a monoclonal antibody indicates that, although the LH receptor signal increases at mid-cycle, it is present at the spokes of vascular invasion only, interpreted as restriction to the theca descendants (Meduri et al., 1996). In contrast, in situ analysis indicates that both large and small cells throughout the pig corpus luteum contain LH receptor mRNA (Yuan and Lucy, 1996). Furthermore, LH receptor mRNA and protein were highly abundant, as demonstrated by RT-PCR and immunolocalization in large and small cell populations isolated from pig corpus luteum (Kaminski et al., 2000). Data from the corpus luteum and the large number of studies demonstrating luteinized granulosa cell responses to LH (Murphy and Silavin, 1989) provide evidence for the persistence of the $\mathrm{LH}$ receptor on both theca and granulosa descendants in pig corpora lutea.

\section{Transcriptional regulation of luteinization}

The subject of transduction of signals and signalling pathways involved in luteinization has been reviewed recently (Murphy, 2000). Hence, in the present review, greater emphasis is placed on gene transcription and its role in the intricacies of corpus luteum formation. Transcription is not the sole regulator of gene expression, but it is clearly the most significant. It is a complex process that includes chromatin modification, coactivator recruitment, and synthesis and activation of transcription factors. Frequently, two or more transcription factors interact to produce differential 
expression of a gene. As noted above, luteal formation involves changes in the expression of numerous known, and presumably many more unknown, gene products. It is not within the scope of this review to consider all permutations; thus, we will focus on factors known to act on genes related to steroidogenesis and to provision of steroid substrate. Where pertinent, factors involved in differentiation and exit from the cell cycle are also discussed.

The classic linear route for transduction of gonadotrophin signals is via CAMP activation of protein kinase $A$ and subsequent phosphorylation of CAMP response binding protein (CREB; Richards, 2001b). CREB exists in three isoforms and is considered to be synthesized constitutively (Zeleznik and Somers, 1999). Phosphorylated CREB transactivates gonadotrophin-regulated steroidogenic genes including P450scc (Watanabe et al., 1994) and P450aromatase (Michael et al., 1997). StAR transcription, which is dependent on cAMP (Stocco, 2001), is modulated by CREB phosphorylation (D. M. Stocco, personal communication). Similarly, transcription of pig Niemann-Pick $C$ protein 1 (NPC-1) is CREBdependent (N. Gévry and B. D. Murphy, unpublished). Little is known about CREB expression in pigs, other than that its coding sequence is found in the pig genome (R. L. Mattari and J. A. Carroll; GenBank Accession U95009). Notwithstanding, in primates, CREB expression is abolished in granulosa cells during luteinization (Somers et al., 1995). These observations are consistent with a model in which $\mathrm{LH}$ acts through CAMP to initiate luteinization of granulosa cells, which then become refractory to this messenger (Zeleznik and Somers, 1999). This view is not compatible with observations that $\mathrm{LH}$ and CAMP can stimulate progesterone from large and small pig luteal cells in vitro (Hunter, 1981) and that exogenous LH increases circulating progesterone concentrations from the pig corpus luteum (Watson and Maule Walker, 1978).

Among the transcription factors implicated clearly in luteinization is the CCAAT/enhancer binding protein $\beta$ (C/EBP- $\beta$ ). C/EBP- $\beta$ expression is induced rapidly in rat granulosa cells in response to an ovulatory dose of hCG (Sirois and Richards, 1993), and granulosa cells in the C/EBP- $\beta$ knockout mice do not luteinize (Sterneck et al., 1997). Furthermore, antisense inhibition of C/EBP- $\beta$ expression interferes with ovulation and luteinization in rats, with no apparent reduction in COX-2 expression (Pall et al., 1997). C/EBP- $\beta$ is a transactivator of StAR transcription (Reinhart et al., 1999). C/EBP- $\beta$ is present in pigs and its expression changes during adipocyte differentiation in vitro (Yu and Hausman, 1998). Therefore, it is likely that C/EBP- $\beta$ expression will prove to be a vital controlling factor in luteinization in pigs.

The six transcription factors (GATA 1-6) of the GATA family are proteins with two zinc fingers that bind to the consensus promoter elements (AT)GATA(AVG) (Molkentin, 2000). The GATA-1, -2 and -3 subfamily regulates haematopoeisis and lymphopoiesis primarily, whereas the subfamily comprising GATA-4, -5 and -6 is expressed in endoderm-derived tissues, including the cardiovascular and digestive systems (Molkentin, 2000). Modulation of the abundance of GATA transcription factors is associated with luteinization in mice and expression of one isoform, GATA-4, is reduced in the follicle after ovulation, whereas GATA-6 is expressed highly in both developing and mature corpora lutea (Heikinheimo et al., 1997). In contrast, GATA-4 is expressed constitutively in rat granulosa cells and interacts with acutely regulated C/EBP- $\beta$ in induction of StAR transcription (Silverman et al., 1999). GATA-4 induces transcription of both StAR and P450aromatase in mouse ovaries (Tremblay and Viger, 2001). Deletion and mutational analysis of the mouse StAR promoter demonstrated that the GATA-4 element interacts with other enhancers, including steroid factor 1 (SF-1) and AP-1, in translating the CAMP stimulus (Wooten-Kee and Clark, 2000). Both the pig StAR and NPC-1 (N. Gévry and B. D. Murphy, unpublished) promoters have GATA response elements within the first 200 bp upstream of the ATG transcription start site. Given the importance of StAR and NPC-1 for luteinization in pigs, it is likely that GATA-directed transcription contributes to the synthesis of progesterone in this species. 
Other transcription factors essential to luteal steroidogenesis are the sterol regulatory element binding proteins (SREBPs). There are three known isoforms of this basic-helix-loophelix-leucine zipper protein: SREBP-1a and -1c (also known as ADD-1) are the products of alternative splicing, whereas SREBP-2 arises from a second gene (Osborne, 2000). The SREBPS are present in cells as integral membrane proteins embedded in the endoplasmic reticular or nuclear membranes (Brown and Goldstein, 1999). In the event of intracellular sterol depletion, a second element, sterol cleavage-activating protein, cleaves the $\mathrm{N}$-terminal SREBP fragment, which then relocates to the nucleus and interacts with decanucleotide segments of the gene promoters (Brown and Goldstein, 1999). Transcription of genes associated with increased intracellular cholesterol is induced, including the cascade for de novo cholesterol synthesis and those related to low density lipoprotein (LDL) receptor-mediated cholesterol importation. Given the increases in cholesterol required to accomplish luteal synthesis of progesterone, it is not surprising that SREBP isoforms are important regulators of de novo synthesis and importation of cholesterol into the corpus luteum (Lopez and McLean, 1999; Shea-Eaton et al., 2001). In addition, over-expression of transcriptionally active SREBP-1a, -1c and -2 increases transcription of StAR (Christenson et al., 2001; Shea-Eaton et al., 2001) and SREBP-1a synergizes with CAMP induction of StAR transcription (Z. T. Ruiz-Cortes and B. D. Murphy, unpublished). Nevertheless, basal StAR transcription in human granulosa lutein cells appears to be unaffected by sterol depletion or repletion and, thus, the physiological significance of SREBP in regulation of StAR is unclear (Christenson et al., 2001). SREBPs appear to have the greatest effects on transcription in concert with other factors and may also integrate endocrine signals. Recent evidence indicates that CAMP may act via CREB to amplify SREBP-mediated transcription of HMG-CoA-reductase (Dooley et al., 1999). Downstream signals in the mitogen-activated kinase pathway stimulate SREBP-induced transcription of the LDL promoter directly (Kotzka et al., 2000). Induction of StAR transcription involves interaction of SREBP with Yin Yang 1 (YY1) (Christenson et al., 2001) and the orphan nuclear receptor of the steroid-thyroid superfamily, SF-1 (Shea-Eaton et al., 2001). Thus, the SREBPS are important in luteinization. They may act on cholesterol homeostasis genes in the corpus luteum and also on transcription of StAR, a key step in luteinization of granulosa cells.

SF- $\boldsymbol{1}$ is implicated in luteinization and steroidogenesis (Wehrenberg et al., 1997). It is essential for expression of StAR, key steroidogenic enzymes (Hanley et al., 2000) and nonsteroidogenic proteins specific to bovine luteinization (Ivell et al., 1999). In equine follicles, SF-1 expression decreases between the ovulatory stimulus and expulsion of the oocyte (Boerboom et al., 2000). In rat granulosa cells, a reduction in SF- 1 expression occurs concomitantly with the decrease in P450aromatase expression (Fitzpatrick et al., 1997). SF-1 expression recovers during early development of the ovine corpus luteum and is expressed constitutively during the mid-luteal phase (Juengel et al., 1998). Pig SF-1 has been identified and sequenced, and is present in the pig corpus luteum of pregnancy (Pilon et al., 1998). Its pattern of expression during luteal formation has not been investigated.

The peroxisome proliferator-activated receptors (PPARs), another group of receptors of the steroid-thyroid superfamily, are potential effectors of luteinization. Three distinct isoforms, PPAR $\alpha, \gamma$ and $\delta$ (also known as PPAR $\beta$ ) are recognized. Each is encoded by a separate gene and has different patterns of tissue and developmental distribution (Chinetti et al., 2000). PPARs require a ligand to be activated and after activation, they form heterodimers with the retinoic acid $X$ receptor $(R X R)$ and interact with specific PPAR response elements in the promoter regions of target genes (Chinetti et al., 2000). Natural ligands include eicosanoides derived from arachidonic acid catalysed by COX-2 (for example 15-deoxy-D-12-14prostaglandin $\mathrm{J} 2$ (PGJ2) and prostacyclin) and 15-hydroxyeicosatetranoic acid (15-HETE), derived from catalysis of lipo-oxygenase (Chinetti et al., 2000). Linoleic acid metabolites, 
including 9- and 12-hydroxydecadanoic acid (9- and 12-HODE), which are also catalysed by lipo-oxygenases, also serve as natural ligands (Chinetti et al., 2000). The thiazolidinedione family of synthetic compounds, the members of which are effective in treatment of noninsulin dependent diabetes, are high affinity ligands for PPAR $\gamma$. Two splice variants of PPAR $\gamma$ are recognized, and PPAR $\gamma 2$ is expressed highly in adipose tissue and involved in terminal differentiation of adipocytes (Hansen et al., 1999). In adipose tissue, a PPAR $\gamma$-induced cell cycle inhibition occurs in tandem with an increase in intracellular concentrations of p27 Kip1 (Motomura et al., 2000; Wakino et al., 2000), which, as noted above, is related to the mechanism of cell cycle exit during luteinization in mice and rats (Robker and Richards, 1998). PPAR $\delta$ has been implicated in adipocyte proliferation (Hansen et al., 2000). All three PPARs are expressed in pigs (Grindflek et al., 1998; Houseknecht et al., 1998; Ding et al., 2000). PPAR $\alpha$ transactivates pig HMG-CoA reductase (Ortiz et al., 1999). PPAR $\gamma$ mRNA is present in pig granulosa cells during luteinization in vitro (Z. T. Ruiz-Cortés and B. D. Murphy, unpublished). Furthermore, a role for PPAR $\gamma$ in luteinization is apparent, on the basis of studies that demonstrate stage-specific expression in bovine luteal cells (Lohrke et al., 1998; Viergutz et al., 2000). A preliminary report indicates that PPAR $\gamma$ is expressed in theca and granulosa cells of pig preovulatory follicles and appears to be related to luteal differentiation (Schoppee et al., 2000). Mechanistic information comes from studies of bovine luteal cells (Lohrke et al., 1998) and pig granulosa cells (Gasic et al., 1998; Schoppee et al., 2000) in which trogladizone (a thiazolidinedione) and PGJ2 cause dose-dependent increases in steroid synthesis. Trogladizone also interferes with $3 \beta$-HSD expression in pig granulosa cells (Gasic et al., 1998); it is not known whether this is mediated by PPAR $\gamma$. Trogladizone reduces P450aromatase expression and activity in human granulosa cells (Mu et al., 2000) and PGJ2 interferes with the cell cycle in bovine luteal cells (Viergutz et al., 2000), thereby further implicating this receptor in luteinization.

Expression of PPARs is induced by other transcription factors involved in luteinization. $\mathrm{C} / \mathrm{EBP} \alpha$ upregulates PPAR $\gamma(\mathrm{Wu}$ et al., 1999), as do endogenous lipid ligands produced as a result of SREBP expression (Patel et al., 2001). In similar experiments, over-expression of SREBP induced transcription of PPAR $\gamma$ (Fajas et al., 1999). PPARs may also influence corpus luteum formation and function by interactions with CREB (Mizukami and Taniguchi, 1997). Over-expression of SREBPs enhances transactivation of target genes by PPAR (Fajas et al., 1999). Mice bearing the null mutation for PPAR $\alpha$ have disrupted expression of SREBPregulated cholesterol and fatty acid metabolism genes (Patel et al., 2001). Thus, the PPAR family of nuclear receptors is involved in the process of luteinization and understanding its impact awaits further experimentation.

\section{Conclusion: models and mechanisms of formation of the pig corpus luteum}

Several pieces in the 'puzzle of luteinization' are now in place, but not enough for the full picture to emerge. An attempt can be made, albeit rife with speculation, to model the changes and mechanisms of early luteal development from the theca and granulosa components of preovulatory pig follicles. The events that are known to occur in pig theca cells during luteinization in vivo after the LH surge, steroid synthesis, proliferation, hypertrophy and migration, are shown (Fig. 3a). LH and CAMP upregulate StAR and other steroidogenic enzymes in the theca (Zhang et al., 2000), presumably working through the linear pathway via phosphorylation of CREB. StAR and steroidogenic enzymes require the orphan nuclear receptor SF-1 for their expression. Serum and growth factors are potent stimulators of theca cell mitosis (May et al., 1992), acting via tyrosine kinases, protein kinase C and mitogenactivated kinase pathways. Theca cell hypertrophy is observed during luteal formation 
(a) Theca cells, 0-72 $\mathrm{h}$ after the ovulatory stimulus

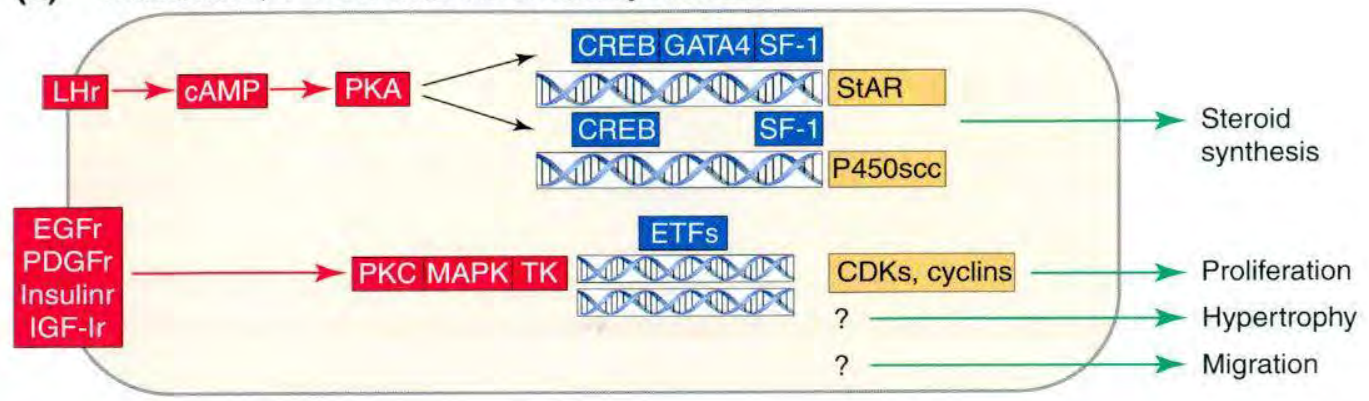

(b) Granulosa cells, $0-72 \mathrm{~h}$ after the ovulatory stimulus

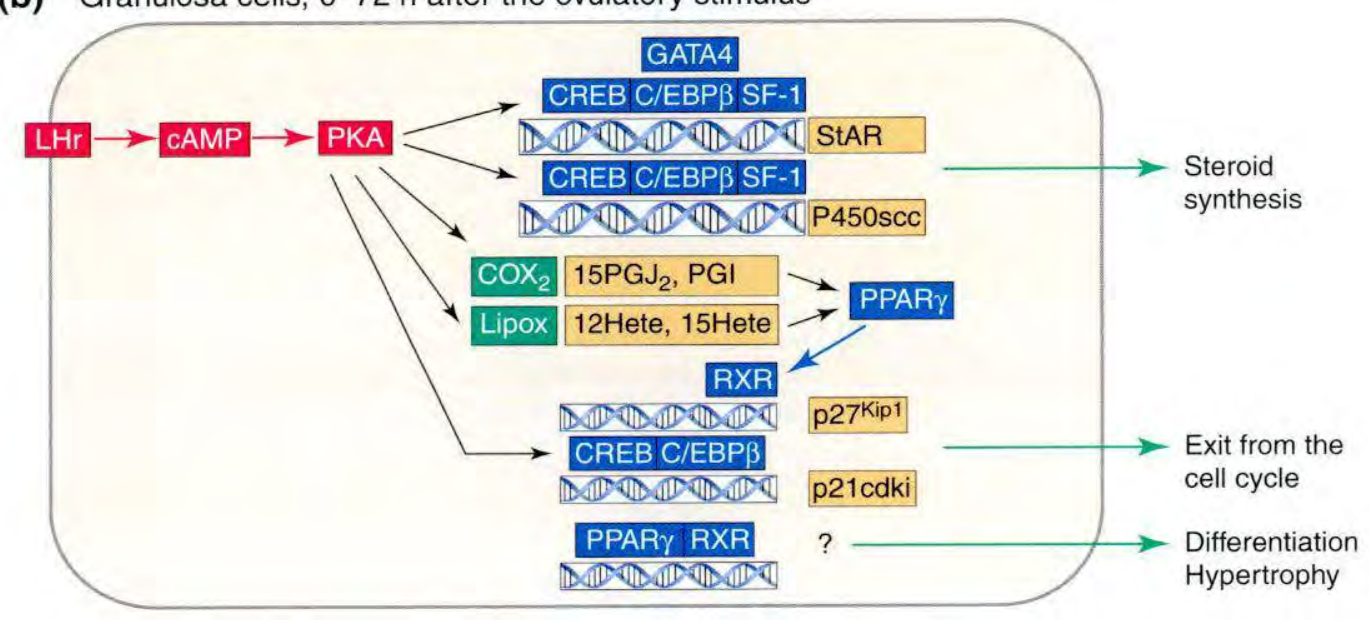

(c) Cells of the corpus luteum through the luteal phase

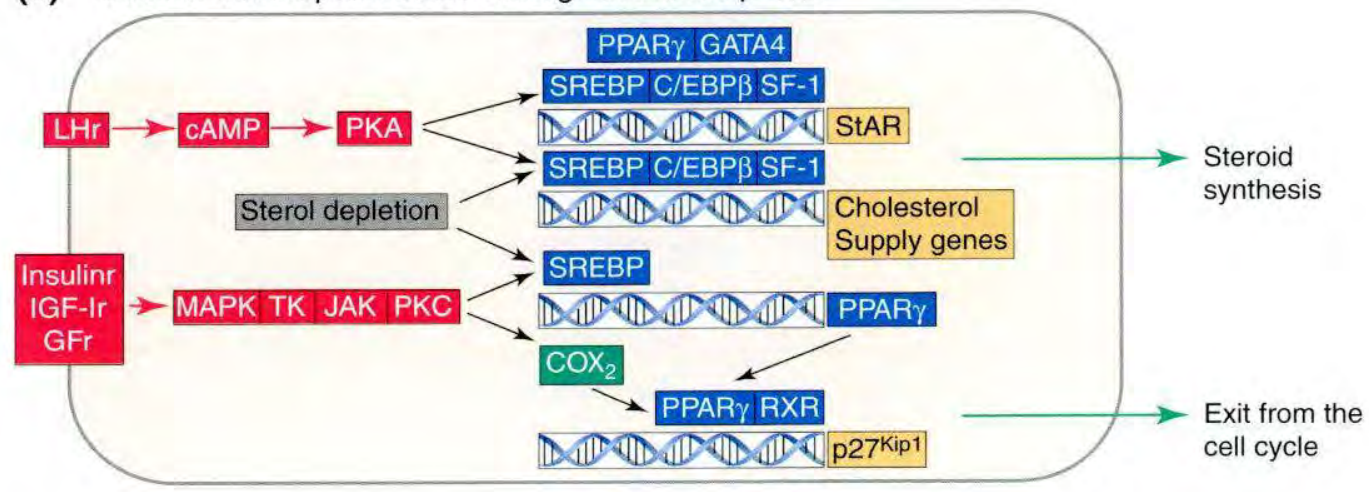

Fig. 3. Summary of the changes and regulation of luteinization in pigs. Elements in red are ligand pathways, blue are transcription factors and yellow are examples of regulated genes. (a) Theca cell between the preovulatory surge and approximately $24 \mathrm{~h}$ after ovulation. (b) Granulosa cell over the same period as in (a). (c) Generalized luteal cell during the early luteal phase. LHr: LH receptor; PKA: protein kinase A; CREB: cAMP response binding protein; GATA4: transcription factor GATA4; SF-1: steroid factor 1; StAR: steroidogenic acute regulatory protein; P450scc: cytochrome P450 side chain cleavage protein; EGFr: epidermal growth factor receptor; PDGFr: platelet-derived growth factor receptor; Insulinr: insulin receptor; IGF-Ir: insulin-like growth factor I receptor; PKC: protein kinase C; MAPK: mitogen-activated protein kinase; TK: tyrosine kinase; ETF: ETF transcription factor family; CDK: cyclin-dependent kinase; C/EBP $\beta$ : CCAAT/enhancer binding protein $\beta$; $\mathrm{COX}_{2}$ : cyclo-oxygenase enzyme; Lipox: lipo-oxygenase; PPAR $\gamma$ : peroxisome proliferator-activated receptor $\gamma$; 
(Corner, 1919) and the migration of theca cells into the granulosa compartment is described in detail above. The factors controlling these profound and important changes are not currently known.

More is known about early events in granulosa cell differentiation, but a coherent synthesis eludes us. An attempt to reconcile available findings is shown (Fig. $3 \mathrm{~b}$ ). LH receptors appear at the antral follicle stage and respond to the ovulatory surge by expression of a number of genes, including COX-2. Given the role of lipoxygenase in ovulation (Downey et al., 1998), its products may also be present during early luteinization. Both enzymes produce ligands for PPAR $\gamma$, which induces differentiation and exit from the cell cycle in adipocytes. Therefore, PPARy may serve multiple roles in granulosa cell luteinization: induction of differentiation, stimulation of steroidogenesis and initiation of exit from the cell cycle. Not represented in the scheme (Fig. 3b) are the roles of insulin and growth factors, which synergize with LH to convert granulosa cells to the luteal phenotype. In early luteinization in other species, CREB isoforms are present, and CAMP and CREB upregulate StAR expression and enzymes in the steroidogenic cascade. $\mathrm{LH}$ induces expression of C/EBP- $\beta$ in preovulatory follicles, and this factor, together with GATA-4 and SF-1, enhances the transcription of StAR. The morphological evidence indicates that hypertrophy of granulosa cells is present as early as $24 \mathrm{~h}$ after ovulation or by $72 \mathrm{~h}$ after the ovulatory stimulus. The cellular events of hypertrophy and their mechanisms of control are not well understood.

The corpus luteum continues to evolve over its lifespan and, likewise, its regulation undergoes an evolution. Given the differential origin and variation in cell size of pig luteal cells, differing regulatory mechanisms must also exist. For simplicity, these have been generalized (Fig. $3 \mathrm{C}$ ). The pituitary factors, LH and prolactin, are necessary for continued luteal steroidogenesis. If, as in other species, CREB is not expressed during luteinization, $\mathrm{LH}$ and CAMP must be acting through other mechanisms, perhaps independent of protein kinase A (Richards, 2001b). A role for SREBP is proposed via its classic effects on the genes that supply cholesterol, regulated by intracellular sterol concentrations. It may have a second role in transcriptional regulation of PPAR $y$ expression, and SREBP may be involved in expression of ligands that activate PPAR $\gamma$. As noted above, COX-2 expression is evident during the mid- and late luteal phases of the pig oestrous cycle (Diaz et al., 2000) and may be a further source of ligands for PPAR $\gamma$. This receptor then has pleiotropic effects on the luteal cell, ensuring the completion of differentiation and exit from the cell cycle, and stimulating steroidogenesis directly. Growth factors and insulin participate in sterol homeostasis and in steroid synthesis via their effects on StAR and receptor-mediated importation of extracellular cholesterol.

The original work described in this review was funded by CIHR grants MT-11018 to B. D. Murphy and MT13190 to J. Sirois, and by a NSERC Strategic Grant 202133-97 to B. D. Murphy and B. R. Downey. Z. T. RuizCortés is on leave from Universidad de Antioqua, Colombia. The authors are grateful to $\mathrm{M}$. Dobias for technical assistance and S. Ledoux for artwork.

Fig. 3. continued

15PGI2: 15-deoxy-D-12-14-prostaglandin 12; PGI: prostaglandin I; 12Hete: 12-hydroxyeicosatetranoic acid; 15Hete: 15-hydroxyeicosatetranoic acid; RXR: retinoic acid X receptor; SREBP: sterol regulatory element binding protein; GFr: growth factor receptor; JAK: janus kinase. 


\section{References}

Barboni B, Turriani $M$, Galeati $G$, Spinaci $M$, Bacci $M L$, Forni $M$ and Mattioli $M$ (2000) Vascular endothelial growth factor production in growing pig antral follicles Biology of Reproduction 63 858-864

Boerboom D, Pilon N, Behdjani R, Silversides DW and Sirois J (2000) Expression and regulation of transcripts encoding two members of the NR5A nuclear receptor subfamily of orphan nuclear receptors, steroidogenic factor-1 and NR5A2, in equine ovarian cells during the ovulatory process Endocrinology $1414647-4656$

Brown MS and Goldstein JL (1999) A proteolytic pathway that controls the cholesterol content of membranes, cells, and blood Proceedings National Academy of Sciences USA $9611041-11048$

Chedrese PJ, Rajkumar K, Ly H and Murphy BD (1988) Dose response of luteinized porcine granulosa cells in vitro to prolactin: dependency on pre-exposure to human chorionic gonadotrophin Canadian Journal of Physiology and Pharmacology 66 1337-1340

Chinetti G, Fruchart IC and Staels B (2000) Peroxisome proliferator-activated receptors (PPARs): nuclear receptors at the crossroads between lipid metabolism and inflammation inflammation Research 49 497-505

Christenson LK, Osborne TF, McAllister IM and Strauss JF, III (2001) Conditional response of human steroidogenic acute regulatory protein gene promoter of sterol regulatory element binding protein 1a Endocrinology 142 28-36

Classen $M$ and Dyson $N$ (2001) p107 and p130: versatile proteins with interesting pockets Experimental Cell Research 264 135-147

Corner GW (1919) On the origin of the corpus luteum of the sow from both granulosa and theca interna American Journal of Anatomy 27 117-183

Coté F, Sirois 1, Doré $M$ and Downey BR (2001) Induction oí prostaglandin $\mathrm{G} / \mathrm{H}$ synthase-2 in preovulatory follicles of equine chorionic gonadotropin/human chorionic gonadotropin treated prepubertal gilts Biology of Reproduction 63 (Supplement 1) 161 (Abstract)

Cox NM (1997) Control of follicular development and ovulation rate in pigs fournal of Reproduction and Fertility Supplement 52 31-46

Diaz FJ, Crenshaw TD and Wiltbank MC (2000) Prostaglandin F2a induces distinct physiological responses in porcine corpora lutea after acquisition of luteolytic capacity Biology of Reproduction 63 1504-1512

Ding ST, Schinckel AP, Weber TE and Mersmann HJ (2000) Expression of porcine transcription factors and genes related to fatty acid melabolism in different tissues and genetic populations fournal of Animal Science $\mathbf{7 8}$ 2127-2134

Dooley KA, Bennett MK and Osborne TF (1999) A critical role for CAMP response element-binding protein (CREB) as a co-activalor in sterol-regulated transcription of 3-hydroxy-3-methylglutaryl coenzyme A synthase promoter Journal of Biological Chemistry 274 5285-5291

Downey BR, Mootoo JE and Doyle SE (1998) A role for lipoxygenase metabolites of arachidonic acid in porcine ovulation Animal Reproduction Science 49 269-279

Driancourt MA, Quesnel H, Meduri G, Prunier A and Hermier D (1998) Luteinization and proteolysis in ovarian follicles of Meishan and Large White gilts during the preovulatory period fournal of Reproduction and Fertility 114 287-297

du Mesnil du Buisson F and Dauzier L. (1957) Influence d'ovariectomie chez la truie pendant la gestation Compte Rendu Societé de Biologie $151311-313$

Ellicott AR and Dzuik PJ (1973) Minimum daily dose of progesterone and plasma concentration for maintenance of pregnancy in ovariectomized gilts Biology of Reproduction 9 300-304

Englehardt H, Gore-Langton RE and Armstrong DT (1991) Luteinization of porcine theca cells in vitro. Molecular and Cellular Endocrinology 75 237-245

Fajas L, Schoonjans K, Gelman L et al. (1999) Regulation of peroxisome proliferator-activated receptor gamma expression by adipocyte differentiation and determination factor $1 /$ sterol regulatory element binding protein 1 : implications for adipocyte differentiation and metabolism Molecular and Cellular Biology 19 5495-5503

Fitzpatrick SL, Carlone DL, Robker RL and Richards IS (1997) Expression of aromatase in the ovary: downregulation of mRNA by the ovulatory luteinizing hormone surge Steroids 62 197-206

Fraser HM and Lunn SF (2001) Regulation and manipulation of angiogenesis in the primate corpus luteum Reproduction 121 355-362

Gasic S, Bodenburg Y, Nagamani M, Green A and Urban RJ (1998) Troglitazone inhibits progesterone production in porcine granulosa cells Endocrinology 139 4962-4966

Gebarowska D, Ziecik AJ and Gregoraszczuk EL (1997) Luteinizing hormone receptors on granulosa cells from preovulatory follicles and luteal cells throughout the oestrous cycle of pigs Animal Reproduction Science 49 191-205

Grant SA, Hunter MG and Foxcroft GR (1989) Morphological and biochemical characteristics during ovarian follicular development in the pig fournal of Reproduction and Fertility 86 171-183

Green C, Chatterjee R, McGarrigle HHG, Ahmed F and Thomas NSB (2000) p107 is active in the nucleolus of non-dividing human granulosa lutein cells journal of Molecular Endocrinology 25 275-286

Grindflek E, Sundvold H, Klungland $\mathbf{H}$ and Lien S (1998) Characterisation of porcine peroxisome prolíieratoractivated receptors gamma 1 and gamma 2: detection of breed and age differences in gene expression Biochemical and Biophysical Research Communications 249 713-718

Guthridge M, Schmitt J, Bertolini J, Cowling J, Runting A, Katsahambas S, Drummond AE and Hearn MT (1992) Studies on basic fibroblast growth factor (FGF-beta) gene expression in the rat and pig ovary using in situ hybridization and quantitalive reverse transcriptasepolymerase chain reaction techniques7 EXS (Basel) 61 219-229

Hampl A, Pachernik J and Dvorak P (2000) Levels and 
interactions of p27, cyclin D3 and CDK4 during the formation and maintenance of the corpus luteum in mice Biology of Reproduction 62 1393-1401

Hanley NA, Ikeda $Y$, Luo $X$ and Parker KL (2000) Steroidogenic factor 1 (SF-1) is essential for ovarian development and function Cellular and Molecular Endocrinology $16327-32$

Hansen JB, Petersen RK, Larsen BM, Bartkova J, Alsner J and Kristiansen $K$ (1999) Activation of peroxisome proliferator-activated receptor gamma bypasses the function of the retinoblastoma protein in adipocyte difíerentiation Journal of Biological Chemistry 274 2386-2393

Hansen JB, Zhang H, Rasmussen TH, Petersen RK, Flindt EN and Kristiansen K (2000) Peroxisome proliferator activator receptor delta (PPARdelta)-mediated regulation of preadipocyte proliferation and gene expression is dependent on CAMP signaling fournal of Biological Chemistry 276 3175-3182

Heikinheimo $M$, Ermolaeva $M$, Bielinska $M$, Rahman NA, Narita N, Huhtaniemi IT, Tapanainen JS and Wilson DB (1997) Expression and hormonal regulation of transcription factors CATA-4 and GATA- 6 in the mouse ovary Endocrinology $1383505-3514$

Houseknecht KL, Bidwell CA, Portocarrero CP and Spurlock ME (1998) Expression and CDNA cloning of porcine peroxisome proliferator-activated receptor gamma (PPARgamma) Cene 225 89-96

Hunter MG (1981) Responsiveness in vitro of porcine luteal tissue recovered al two stages of the luteal phase fournal of Reproduction and Fertility $63471-476$

Hunter RHF (1972) Ovulation in the pig: timing in response to injection of human chorionic gonadotrophin Research in Veterinary Science 13 356-361

Ivell R, Bathgate $R$ and Walther $N$ (1999) Luteal peptides and their genes as important markers of ovarian differentiation Journal of Reproduction and Fertility Supplement 54 207-216

Juengel JL, Larrick TL, Meberg BM and Niswender GD (1998) Luteal expression of steroidogenic factor-1 mRNA during the estrous cycle and in response to luteotropic and luteolytic stimuli in ewes Endocrine 9 227-232

Kaminski T, Gawronska B, Derecka K, Okrasa S and Przala J (2000) Gene expression and peptide localization for $\mathrm{L} . \mathrm{H} / \mathrm{hCG}$ receptor in porcine small and large luteal cells: possible regulation by opioid peptides journal of Physiology and Pharmacology 51 359-368

Kikokawa $\mathrm{H}$, Kineman RD, Manova-Todorova $\mathrm{KO}$ et al. (1996) Enhanced growth of mice lacking cyclindependent kinase inhibitor function of p27(Kip1) Ce// 31 721-732

Kotzka J, Muller-Wieland D, Roth G, Kremer L, Munck M, Schurmann S, Knebel B and Krone W (2000) Sterol regulatory element binding proteins (SREBP)-1a and SREBP-2 are linked to the MAP-kinase cascade fournal of Lipid Research 41 99-108

Lavoie HA, Benoit AM, Garmey IC, Dailey RL, Wright DJ and Veldhuis ID (1997) Coordinate developmental expression of genes regulating sterol economy and cholesterol side chain cleavage in the porcine ovary Biology of Reproduction $57402-407$
Lemon $M$ and Loir $L$ (1977) Steroid release in vitro by two luteal cell types in the corpus luteum of the pregnant sow Journal of Endocrinology 72 351-359

Li Y, Molina JR, Klindt J, Bolt DJ and Anderson LL (1989) Prolactin maintains relaxin and progesterone secretion by aging corpora lutea after hypophysial stalk transection or hypophyseclomy in the pig Endocrinology 124 1294-1304

Liu J, Aronow BJ, Wilte DP, Pope WF and La Barbera AR (1998) Cyclic and maturation-dependent regulation of follicle-stimulating hormone receptor and luteinizing hormone receptor messenger ribonucleic acid expression in the porcine ovary Biology of Reproduction 58 648-658

Lohrke B, Viergutz T, Shahi SK, Pohland R, Wollenhaupt K, Coldammer T, Walzel $H$ and Kanitz W (1998) Detection and functional characterisation of the transcription factor peroxisome proliferator-activated receptor gamma in lutein cells Journal of Endocrinology $159429-439$

Lopez D and McLean MP (1999) Sterol regulatory elementbinding protein-1a binds to cis elements in the promoter of the rat high density lipoprotein receptor SR-BI gene Endocrinology 140 5669-5681

May IV, Bridge AI, Gotcher ED and Gangrade BK (1992) The regulation of porcine theca cell proliferation in vitro: synergistic actions of epidermal growth factor and platelet-derived growth factor Endocrinology 131 689-697

Meduri G, Vu Hai MT, Jolivet A, Takemori S, Kominami S, Driancourt MA and Milgrom E (1996) Comparison of cellular distribution of $\mathrm{LH}$ receptors and steroidogenic enzymes in the porcine ovary Journal of Endocrinology $148435-446$

Michael MD, Michael LF and Simpson ER (1997) A CRE-like sequence that binds CREB and contributes to CAMPdependent regulation of the proximal promoter of the human aromatase P450 (CYP19) gene Molecular and Cellular Endocrinology 134 147-156

Mizukami I and Taniguchi T (1997) The antidiabetic agent thiazolidinedione stimulates the interaction between PPAR gamma and CBP Biochemical and Biophysical Research Communications 240 61-64

Molkentin ID (2000) The zinc-finger containing transcription factors GATA-4, -5 and -6 Journal of Biological Chemistry 5038 949-38952

Morbeck DE, Esbenshade KL, Flowers WL and Britt JH (1992) Kinetics of follicle growth in the prepubertal gilt Biology of Reproduction $47485-491$

Morgan DO (1995) Principles of CDK regulation Nature 374 131-134

Motomura W, Okumura T, Takahashi N, Obara T and Kohgo $Y(2000)$ Activation of peroxisome proliferator-activated receptor gamma by troglitazone inhibits cell growth through the increase of $\mathrm{p} 27 \mathrm{KiP} 1$ in human pancreatic carcinoma cells Cancer Research 60 5558-5564

Mu YM, Yanase T, Nishi Y, Waseda N, Oda T, Tanaka A, Takayanagi R and Nawata $H(2000)$ Insulin sensitizer, troglitazone, directly inhibits aromatase aclivity in human ovarian granulosa cells Biochernical and Biophysical Research Communications 271 710-713

Murphy BD (2000) Models of luteinization Biology of Reproduction 63 2-11 
Murphy BD and Silavin SL (1989) Luteotropic agents and steroid substrate utilization Oxford Reviews of Reproductive Biology 11 180-223

Ortiz JA, Mallolas J, Nicot C, Bofarull J, Rodriguez IC, Hegardt FG, Haro D and Marrero PF (1999) Isolation of pig mitochondrial 3-hydroxy-3-methylglutaryl-CoA synthase gene promoter: characterization of a peroxisome proliferator-responsive element Biochemical fournal 337 329-335

Osborne TF (2000) Sterol regulatory element binding proteins (SREBPS): key regulators of nutritional homeoslasis and insulin action Journal of Biological Chemistry 27532 379-32 382

Pall M, Hellberg P, Brannstrom M, Mikuni M, Peterson CM, Sundfeldt K, Norden B, Hedin L and Enerback S (1997) The transcription factor $C$ EBP. $\beta$ and its role in ovarian function; evidence for direct involvement in the ovulatory process EMBO Journal 16 5273-5279

Patel DD, Knight BL, Wiggins D, Humphreys SM and Cibbons GF (2001) Disturbances in the normal regulation of SREBP-sensitive genes in PPARalphadeficient mice fournal of Lipid Research 42 328-337

Pescador N, Stocco DM and Murphy BD (1997) Folliclestimulating hormone and intracellular second messengers regulate steroidogenic acute regulatory protein (SIAR) mRNA in luteinized granulosa cells Biology of Reproduction 57 660-668

Pescador N, Stocco DM and Murphy BD (1999) Growth factor modulation of steroidogenic acute regulatory protein and luteinization in the pig ovary Biology of Reproduction 60 1453-1461

Picton HM, Campbell BK and Hunter MG (1999) Maintenance of oestradiol produclion and expression of cytochrome $\mathbf{P 4 5 0}$ aromatase enzyme mRNA in longterm serum-free cultures of pig granulosa cells journal of Reproduction and Fertility 115 67-77

Pilon N, Behdjani R, Daneau I, Lussier JC and Silversides DW (1998) Porcine steroidogenic factor-1 gene (pSF-1) expression and analysis of embryonic pig gonads during sexual differentiation Endocrinology 139 3803-3812

Pitzel L, Hubertus J and Wuttke W(1990) Effects of oxytocin on in vitro steroid release of midstage small and large porcine luteal cells Endocrinology 126 2343-2349

Pope WF, Xie S, Brocrmann DM and Nephew KP (1990) Causes and consequences of early embryonic diversity in pigs Journal of Reproduction and Fertility Supplement $40251-260$

Reinhart AJ, Williams SC, Clark BJ and Stocco DM (1999) SF-1 steroidogenic factor-1 and $C / E . P B-\beta$ CCAAT/Enhancer binding protein- $\beta$ cooperate to regulate the murine SIAR (steroidogenic acute regulatory protein) promoter Molecular Endocrinology 13 729-741

Reynolds L.P, Grazul-Bilska AT and Redmer DA (2000) Angiogenesis in the corpus lutcum Endocrine 12 1-9

Richards IS (2001a) Graafian follicle function and luteinizalion in nonprimates fournal of the Society for Gynecologic Investigation 8 (Supplement 1) S21-\$23

Richards IS (2001b) New signaling pathways for hormones and cyclic adenosine $3^{\prime} 5^{\prime}$-monophosphate action in endocrine cells Journal of Molecular Endocrinology 15 209-218
Richards IS, Russell DL, Robker RL, Dajee $M$ and Alliston TN (1998) Molecular mechanisms of ovulation and luteinization Molecular and Cellular Endocrinology 145 47-54

Ricke WA, Redmer DA and Reynolds LP (1999) Growth and cellular proliferation of pig corpora lutea throughout the estrous cycle Journal of Reproduction and Fertility 117 369-377

Robker RL and Richards IS (1998) Hormone-induced proliferation and differentiation of granulosa cells: a coordinated balance between cell cycle regulators D2 and $\mathrm{p} 27^{\mathrm{Kip} / \mathrm{I}}$ Molecular Endocrinology 12 924-940

Schoppee PD, Guthrie HD and Veldhuis ID (2000) Expression of peroxisome proliferator activated receptor $\gamma$ (PPAR $\gamma$ ) is associated with specific stages of follicular cell differentiation in porcine ovaries Biology of Reproduction 62 (Supplement 1) 195-196

Sekar N, Garmey JC and Veldhuis ID (2000) Mechanisms underlying the steroidogenic synergy of insulin and luteinizing hormone in porcine granulosa cells: joint amplification of pivotal sterol-regulatory genes encoding the low-density lipoprotein (LDL.) receptor, steroidogenic acule regulatory (stAR) protein and cytochrome $\mathbf{P} 450$ side-chain cleavage (P450scc) enzyme Molecular and Cellular Endocrinology 159 25-35

Shea-Eaton WK, Trinidad MJ, Lopez D, Nackley A and McLean MP (2001) Sterol regulatory element binding protein-1a regulation of the steroidogenic acute regulatory protein gene Endocrinology 142 1525-1533

Silverman E, Eimerl'S and Orly I (1999) CCAAT enhancerbinding protein $\beta$ and CATA-4 binding regions within the promoter of the steroidogenic acute regulatory protein (StAR) gene are required for transcription in ovarian cells Journal of Biological Chemistry 274 17 987-17996

Sirois I and Richards IS (1992) Purification and characterization of a novel, distinct isoform of prostaglandin endoperoxide synthase induced by human chorionic gonadotropin in granulosa cells of rat preovulatory follicles fournal of Biological Chemistry 267 6382-6388

Sirois I and Richards IS (1993) Transcriptional regulation of the rat prostaglandin endoperoxidase synthase 2 gene in granulosa cells Journal of Biological Chemistry 26821 931-21938

Soede NM, Helmond A and Kemp B (1994) Periovulatory profiles of oestradiol, $\mathrm{LH}$ and progesterone in relation to oestrus and embryonic mortality in multiparous sows using transrectal ultrasonography to detect ovulation Journal of Reproduction and Fertility 101 633-641

Somers JP, Benyo DF, Little-Ihrig LL and Zeleznik AJ (1995) Luteinization in primates is accompanied by a loss of a 43-kilodalton adenosine 3'5'-monophosphate responsc element binding protein isoform Endocrinology 136 $4262-4268$

Song J-H, Dobias M, Pescador N and Murphy BD (1998) Luteinization and gonadotrophins upregulate the Niemann-Pick gene in the porcine ovary Biology of Reproduction 58 (Supplement 1) 188 (Abstract)

Sterneck E, Tessarollo $L$ and Johnson PF (1997) An essential role for C/EBP $\beta$ in remale reproduction Genes and Development 11 2153-2162 
Stocco DM (2001) SIAR protein and the regulation of steroid hormone biosynthesis Annual Reviews of Physiology 63 193-213

Tong W, Kiyokawa H, Soos TJ, Park MS, Soares VC, Manova K, Pollard JW and Koff A (1998) The absence of P27Kip1, an inhibitor of $\mathrm{Gl}$ cyclin-dependent kinases, uncouples differentiation and growth arrest during the granulosaluteal transition Cell Growth and Differentiation 9 787-794

Tremblay JJ and Viger RS (2001) GATA factors differentially activate multiple gonadal promoters through conserved GATA regulatory elements Endocrinology 142 977-986

Tsang BK, Ainsworth L, Downey BR and Marcus GJ (1985) Differential production of steroids by dispersed granulosa and theca interna cells from developing preovulatory follicle in pigs Journal of Reproduction and Fertility 74 459-471

Tsutsui T, Hesabi B, Moons DS, Pandolfi PP, Hansel KS, Koff A and Kiyokawa $\mathbf{H}$ (1999) Targeted disruption of CDK4 delays cell cycle entry with enhanced $\mathrm{p} 27^{\mathrm{Kipl}}$ activity Molecular and Cellular Biology 19 7011-7019

Viergutz T, Loehrke B, Poehland R, Becker F and Kanitz W (2000) Relationship between different stages of the corpus luteum and the expression of the peroxisome proliferator-activated receptor gamma protein in bovine large lutein cells Journal of Reproduction and Fertility 118 153-161

Wakino S, Kintscher U, Kim S, Yin F, Hsueh WA and Law RE (2000) Peroxisome proliferator-activated receptor gamma ligands inhibit retinoblastoma phosphorylation and $G_{1} \rightarrow S$ transition in vascular smooth muscle cells Journal of Biological Chemistry $27522435-22441$

Wandii SA, Gadsby JE, Simmen FA, Barber JA and Hammond JM (2000a) Porcine ovarian cells express messenger ribonucleic acids for the acid-labile subunit and insulin-like growth factor binding protein-3 during follicular and luteal phases of the estrous cycle Endocrinology 141 2638-2647

Wandji SA, Gadsby JE, Barber JA and Hammond JM (2000b) Messenger ribonucleic acids for MAC25 and connective tissue growth factor (CTCF) are inversely regulated during folliculogenesis and early luteogenesis Endocrinology 141 2648-2657

Watanabe $N$, Inoue $H$ and Fujii-Kuriyama $Y$ (1994)
Regulatory mechanisms of the CAMP-dependent and cell specific expression of human steroidogenic P450scc (CYPA11) gene European Journal of Biochemistry 222 825-834

Watson J and Maule Walker FM (1978) Progesterone secretion by the corpus luteum of the early pregnant pig during superfusion in vitro with PGF-2alpha, L.H and oestradiol fournal of Reproduction and Fertility 52 209-212

Wehrenberg $U$, Wulff $C$, Husen $B$, Ken-ichirou $M$ and Rune CM (1997) The expression of SF-1/Ad4BP is related to the process of luteinizalion in the marmoset (Callithrix jacchus) ovary Histochemistry and Cell Biology 107 345-350

Wooten-Kee CR and Clark B) (2000) Steroidogenic factor-1 influences protein-deoxyribonucleic acid interactions within the cyclic adenosine $3^{\prime} 5^{\prime}$-monophosphatcresponsive regions of the murine steroidogenic acute regulatory protein gene Endocrinology 141 1345-1355

Wu Z, Rosen ED, Brun R, Hauser S, Adelmant G, Troy AE, Mckeon C, Darlington $C$ J and Spiegelman BM (1999) Cross-regulation of C/EBP alpha and PPAR gamma controls the transcriptional pathway of adipogenesis and insulin sensitivity Molecular Cel/ 3 151-158

Yu ZK and Hausman GJ (1998) Expression of CCAAT/enhancer binding proteins during porcine preadipocyte differentialion Experimental Cell Research $15343-349$

Yuan W and Lucy MC (1996) Messenger ribonucleic acid expression for growth hormone receptor, luteinizing hormone receptor, and steroidogenic enzymes during the estrous cycle and pregnancy in porcine and bovine corpora lutea Domestic Animal Endocrinology $13431-444$

Zeleznik AJ and Somers IP (1999) Regulation of the primate corpus luteum: cellular and molecular prospectives Trends in Endocrinology and Metabolism 10 $189-193$

Zhang G, Garmey IC and Veldhuis ID (2000) Interactive stimulation by luteinizing hormone and insulin of the steroidogenic acute regulatory (SLAR) protein and 17alpha- hydroxylase/17,20-lyase (CYP17) genes in porcine theca cells Endocrinology $1412735-2742$

Zhu L and Skoultchi Al (2001) Coordinating cell proliferation and differentiation Current Opinion in Genetics and Development 10 91-97 